\title{
Characterization of anti-Listeria bacteriocins isolated from shellfish: Potential antimicrobials to control non-fermented seafood
}

\author{
Ana Luísa Pinto a,b Melissa Fernandes ${ }^{a}$, Cristina Pinto ${ }^{a}$, Helena Albano ${ }^{a}$, Fernanda Castilho ${ }^{b}$, \\ Paula Teixeira $^{\text {a,* }}$, Paul A. Gibbs ${ }^{\text {a,c }}$ \\ a Escola Superior de Biotecnologia, Universidade Católica Portuguesa, R. Dr. António Bernardino de Almeida, 4200-072 Porto, Portugal \\ ${ }^{b}$ Instituto Nacional de Recursos Biológicos, I.P./IPIMAR Matosinhos, Av. Norton de Matos, 4, 4450-208 Matosinhos, Portugal \\ ' Leatherhead Food International, Randalls Road, Leatherhead Surrey KT22 7RY, UK
}

Keywords:

Bacteriocins

Characterization

Seafood

Enterococcus faecium

Pediococcus pentosaceus

Listeria monocytogenes

Biopreservation

\section{A B S T R A C T}

This work had as main objectives to characterize two bacteriocins produced by lactic acid bacteria (LAB) previously isolated from non-fermented seafood, in order to evaluate their potential as new food protective agents. The two bacteriocinogenic isolates were identified by Polymerase Chain Reaction (PCR) using genusand species-specific primers, and confirmed by $16 \mathrm{~S}$ rDNA sequencing, as Enterococcus faecium and Pediococcus pentosaceus. The antimicrobial spectrum of each strain included several indicator microorganisms, some of them also isolated from seafood. Growth of Listeria innocua, L. monocytogenes, Staphylococcus aureus, Bacillus cereus and other LAB species were inhibited, although no inhibition of Gram-negative microorganisms was observed. Proteolytic, but not lipolytic or glycolytic enzymes, completely inactivated the antimicrobial effect of both cell-free supernatants confirming the proteinaceous nature of the inhibitors. The antimicrobial activity was maintained after treatment with $\mathrm{NaCl}$, SDS, Triton X-100, Tween 20, Tween 80 and EDTA after $2 \mathrm{~h}$ or $5 \mathrm{~h}$ of exposure and both bacteriocins were stable over a wide range of $\mathrm{pH}$ and temperatures. Production of bacteriocin by E. faecium (bacALP7) was detected initially at exponential phase and reached a maximum activity of $25,600 \mathrm{AU} / \mathrm{ml}$ in the early stationary phase, whereas bacteriocin production by P. pentosaceus ALP57 (bacALP57) reached the maximum at exponential phase with $12,800 \mathrm{AU} / \mathrm{ml}$. The bacteriocins did not kill $L$. monocytogenes ESB54 nor L. innocua 2030c however, cellular growth was reduced. The partially purified bacteriocins, bacALP7 and bacALP57, were below $6.5 \mathrm{kDa}$ in size as determined by Tricine-SDS gel electrophoresis. E. faecium and P. pentosaceus contained DNA fragments corresponding in size to those recorded for enterocin $B$ and pediocin PA-1, respectively. Sequencing of the fragments from both bacteriocins confirmed the homology. To our knowledge, for the first time two LAB producing bacteriocins similar to pediocin PA- 1 and enterocin $B$, were isolated from non-fermented shellfish. The adaptation of the cultures to seafood matrices may be advantageous in terms of application as a biopreservation strategy for reduction of $L$. monocytogenes levels in seafood products.

\section{Introduction}

Thousands of new fish and seafood products have been prepared and launched worldwide, motivated by the new lifestyles and consumers' demand for new products, more convenient, natural and safe. The new trends constitute considerable challenges to the food and medical industries (Devlieghere et al., 2004). From a natural food preservation point of view, the search for and study of new antimicrobials such as the LAB bacteriocins, generally regarded as safe (GRAS status) (Deegan et al., 2006), are desirable in order to stimulate interest and evaluate industrial potential. Several studies have re-

\footnotetext{
* Corresponding author. Tel.: +351 225580095; fax: +351 225090351.

E-mail address: pcteixeira@esb.ucp.pt (P. Teixeira).
}

ported improvement of the quality and shelf-life of fish products (Katla et al., 2001; Nilsson et al., 2004; Brillet et al., 2005; Calo-Mata et al., 2007). Combination methods have been tested for efficacy of pathogen inhibition in fish and shellfish systems. Examples include synergistic combinations of bacteriocins and other technologies (Zuckerman and Bem Avraham, 2002; Al-Holy et al., 2004; Elotmani and Assobhei, 2004), for instance, active packaging with adsorbed bacteriocins (Chen and Hoover, 2003).

The spectrum of activity of most LAB bacteriocins is rather narrow and may not inhibit the variety of microorganisms found in foods. This is particularly important regarding Gram-negative bacteria. Bacteriocin resistance is also one of the major current limitations for application of bacteriocins in foods (Chen and Hoover, 2003). Moreover, food matrices affect the activity of bacteriocins and growth of bacteria in several ways (Katla et al., 2001). In fact, improvement in knowledge 
and understanding of seafood matrices, their microbial ecology, with particular attention to LAB, would be advantageous. The search for new bacteriocins from fermented and non-fermented food products could open new application horizons in terms of biopreservation.

The occurrence of the food borne pathogen Listeria monocytogenes, the causative agent of listeriosis (Katla et al., 2001), has motivated several studies regarding its control in foods, particularly in those that pose higher degrees of risk. Biopreservation technology has gained special attention for application to minimally processed seafood such as cold-smoked salmon and has been already been promoted as a strategy for L. monocytogenes control in seafood.

L. monocytogenes is able to grow at low temperatures and under conditions of high salt content (Ben Embarek, 1994; Handa et al., 2005; Pinto et al., 2006). In fact, listeriosis outbreaks caused by the consumption of fresh seafood has been reported (Brett et al., 1998). In the same food niche, the presence of LAB has been reported for several fish species (Ringo and Gatesoupe, 1998), seafood products such as surimi (Yamazaki et al., 2003); fresh fish (Bucio et al., 2006), aquacultured fish (Michel et al., 2007), and intestinal contents of marine coastal fish (Itoi et al., 2008). Some strains of Carnobacterium (Pilet et al., 1995; Nilsson et al., 2004; Tahiri et al., 2004), Lactococcus lactis, Enterococcus spp., and Pediococcus spp. (Campos et al., 2006; Tomé et al., 2008) have received attention as bacteriocin-producing cultures. In comparison with other food products such as dairy and meat (Cleveland et al., 2001), few bacteriocinogenic strains and their bacteriocins recovered from aquatic environments, fish products and even less from non-fermented seafood, have been identified and characterized. The acquisition of strains already acclimatized to a seafood habitat would be advantageous in terms of biopreservation (Tahiri et al., 2004), not only to be used as live bacterial (protective) cultures to be applied to foods but also, incorporated into feedstuffs, with application in aquaculture (for a review see Balcázar et al., 2006). Taking this into account, our research group has recently isolated LAB from marine non-fermented shellfish and tested the isolates for antimicrobial activity by bacteriocin production against $L$. monocytogenes. The present study focuses on the characterization of two bacteriocins, produced by E. faecium ALP7 and P. pentosaceus ALP57, obtained from the initial screening.

\section{Materials and methods}

\section{Bacterial strains and cultures conditions}

All LAB strains used in this study were maintained as stock cultures at $-80{ }^{\circ} \mathrm{C}$ in All Purpose Tween (APT) broth (Difco Laboratories, Detroit, USA) and the remaining strains in Brain Heart Infusion (BHI; LAB M, Bury, UK) broth with $30 \%$ (v/v) glycerol. The strains were propagated twice in the respective media at $30{ }^{\circ} \mathrm{C}$ or $37{ }^{\circ} \mathrm{C}$ before use. Reference strains used for the identification tests were E. faecium ESB82, E. faecalis ATCC29212, P. acidilactici PAC-1.0, and $P$. pentosaceus ESB663.

\section{Identification of bacteriocin-producing strains}

The two strains (given code ALP7 and ALP57) used in this study were selected from a group of 78 bacteriocinogenic LAB previously isolated from non-fermented shellfish, including oysters, mussels, and clams. The selection was based on phenotypical studies such as growth at different temperatures, $\mathrm{pH}$, salt content and atmosphere conditions, maintenance of stability and functionality after freezeand spray-drying; antimicrobial activity and inhibition spectrum, and also safety requirements involving antibiotic resistance, biogenic amines production and haemolytic activity (Pinto et al. unpublished results). Before total DNA extraction, the strains were cultivated for $24 \mathrm{~h}$ in APT broth at $30{ }^{\circ} \mathrm{C}$ according to the method described by Dellaglio et al. (1973). Further identification was done
Table 1

Antimicrobial activity spectrum of E. faecium ALP7 and P. pentosaceus ALP57; growth medium and incubation temperature of indicator strains

\begin{tabular}{|c|c|c|c|c|c|}
\hline $\begin{array}{l}\text { Indicator } \\
\text { organism }\end{array}$ & Strain & Source & $\begin{array}{l}\text { Growth } \\
\text { media and } \\
\text { temperature }\end{array}$ & $\begin{array}{l}\text { E. } \\
\text { faecium } \\
\text { ALP7 }\end{array}$ & $\begin{array}{l}P . \\
\text { pentosaceus } \\
\text { ALP57 }\end{array}$ \\
\hline \multicolumn{6}{|l|}{ Gram-negative } \\
\hline $\begin{array}{l}\text { Salmonella } \\
\text { typhimurium }\end{array}$ & $\begin{array}{l}\text { IPIMAR- } \\
\text { SD28 }\end{array}$ & $\begin{array}{l}\text { Seafood } \\
\text { (shellfish) }\end{array}$ & $37^{\circ} \mathrm{C}, \mathrm{BHI}$ & - & - \\
\hline $\begin{array}{l}\text { Salmonella } \\
\text { enteritidis }\end{array}$ & $\begin{array}{l}\text { NCTC } \\
3046\end{array}$ & Unknown & $37^{\circ} \mathrm{C}, \mathrm{BHI}$ & - & - \\
\hline $\begin{array}{l}\text { Salmonella } \\
\text { enteritidis }\end{array}$ & $\begin{array}{l}\text { NCTC } \\
5188\end{array}$ & Unknown & $37^{\circ} \mathrm{C}, \mathrm{BHI}$ & - & - \\
\hline Salmonella spp. & $\begin{array}{l}\text { IPIMAR- } \\
\text { SD1 }\end{array}$ & $\begin{array}{l}\text { Seafood } \\
\text { (shellfish) }\end{array}$ & $37{ }^{\circ} \mathrm{C}, \mathrm{BHI}$ & - & - \\
\hline Escherichia coli & $\begin{array}{l}\text { NCTC } \\
9001\end{array}$ & Urine & $37^{\circ} \mathrm{C}, \mathrm{BHI}$ & - & - \\
\hline Escherichia coli & 0157:H7 & Unknown & $37^{\circ} \mathrm{C}, \mathrm{BHI}$ & - & - \\
\hline Escherichia coli & $\begin{array}{l}\text { ATCC } \\
8739\end{array}$ & Faeces & $37^{\circ} \mathrm{C}, \mathrm{BHI}$ & - & - \\
\hline $\begin{array}{c}\text { Pseudomonas } \\
\text { aeruginosa }\end{array}$ & ESB 03 & Unknown & $37^{\circ} \mathrm{C}, \mathrm{BHI}$ & - & - \\
\hline $\begin{array}{l}\text { Shewanella } \\
\text { putrefaciens }\end{array}$ & $\begin{array}{l}\text { IPIMAR- } \\
\text { SP4 }\end{array}$ & $\begin{array}{l}\text { Seafood } \\
\text { (shellfish) }\end{array}$ & $37^{\circ} \mathrm{C}, \mathrm{BHI}$ & - & - \\
\hline \multicolumn{6}{|l|}{ Gram-positive } \\
\hline $\begin{array}{l}\text { Listeria } \\
\quad \text { monocytogenes }\end{array}$ & ALP211 & $\begin{array}{l}\text { Seafood } \\
\text { (bivalve molluscs) }\end{array}$ & $37^{\circ} \mathrm{C}, \mathrm{BHI}$ & $+++(++)$ & $+++(++)$ \\
\hline $\begin{array}{l}\text { Listeria } \\
\quad \text { monocytogenes }\end{array}$ & ALP17 & $\begin{array}{l}\text { Seafood } \\
\text { (bivalve molluscs) }\end{array}$ & $37^{\circ} \mathrm{C}, \mathrm{BHI}$ & $+++(++)$ & $+++(++)$ \\
\hline $\begin{array}{l}\text { Listeria } \\
\quad \text { monocytogenes }\end{array}$ & ALP18 & $\begin{array}{l}\text { Seafood } \\
\text { (bivalve molluscs) }\end{array}$ & $37^{\circ} \mathrm{C}, \mathrm{BHI}$ & $+++(+)$ & $+++(++)$ \\
\hline $\begin{array}{l}\text { Listeria } \\
\quad \text { monocytogenes }\end{array}$ & $\begin{array}{l}\text { NCTC } \\
10357\end{array}$ & Rabbit & $37{ }^{\circ} \mathrm{C}, \mathrm{BHI}$ & $+++(+)$ & $++(++)$ \\
\hline $\begin{array}{l}\text { Listeria } \\
\quad \text { monocytogenes }\end{array}$ & ESB54 & $\begin{array}{l}\text { Seafood } \\
\text { (smoked salmon) }\end{array}$ & $37^{\circ} \mathrm{C}, \mathrm{BHI}$ & $+++(++)$ & $+++(++)$ \\
\hline $\begin{array}{l}\text { Listeria } \\
\quad \text { monocytogenes }\end{array}$ & $\begin{array}{l}\text { NCTC } \\
11994\end{array}$ & Rabbit & $37^{\circ} \mathrm{C}, \mathrm{BHI}$ & $+++(+)$ & $+++(+)$ \\
\hline $\begin{array}{l}\text { Listeria } \\
\quad \text { monocytogenes }\end{array}$ & $\begin{array}{l}\text { ESB } \\
7946\end{array}$ & "Alheira” * & $37^{\circ} \mathrm{C}, \mathrm{BHI}$ & $+++(+)$ & $+++(+)$ \\
\hline $\begin{array}{l}\text { Listeria } \\
\quad \text { monocytogenes }\end{array}$ & ESB 121 & $\begin{array}{l}\text { Seafood } \\
\text { (smoked salmon) }\end{array}$ & $37^{\circ} \mathrm{C}, \mathrm{BHI}$ & $+++(++)$ & $+++(++)$ \\
\hline Listeria innocua & $\begin{array}{l}\text { NCTC } \\
11288\end{array}$ & Cow brain & $37{ }^{\circ} \mathrm{C}, \mathrm{BHI}$ & +++ & ++ \\
\hline Listeria innocua & $\begin{array}{l}\text { NCTC } \\
10528\end{array}$ & Unknown & $37^{\circ} \mathrm{C}, \mathrm{BHI}$ & ++ & ++ \\
\hline Listeria innocua & ESB 1325 & Unknown & $37^{\circ} \mathrm{C}, \mathrm{BHI}$ & +++ & +++ \\
\hline $\begin{array}{l}\text { Staphylococcus } \\
\text { aureus }\end{array}$ & $\begin{array}{l}\text { ATCC } \\
6538\end{array}$ & Human lesion & $37^{\circ} \mathrm{C}, \mathrm{BHI}$ & - & - \\
\hline $\begin{array}{l}\text { Staphylococcus } \\
\text { aureus }\end{array}$ & $\begin{array}{l}\text { ATCC } \\
29213\end{array}$ & Wound & $37^{\circ} \mathrm{C}, \mathrm{BHI}$ & + & - \\
\hline Bacillus subtilis & $\begin{array}{l}\text { NCTC } \\
3610\end{array}$ & Unknown & $37^{\circ} \mathrm{C}, \mathrm{BHI}$ & + & + \\
\hline Bacillus cereus & $\begin{array}{l}\text { ATCC } \\
11778\end{array}$ & Unknown & $37^{\circ} \mathrm{C}, \mathrm{BHI}$ & + & - \\
\hline Bacillus cereus & $\begin{array}{l}\text { NCTC } \\
2599\end{array}$ & Unknown & $37^{\circ} \mathrm{C}, \mathrm{BHI}$ & - & - \\
\hline $\begin{array}{l}\text { Pediococcus } \\
\text { acidilactici }\end{array}$ & ESB 663 & Meat & $30{ }^{\circ} \mathrm{C}, \mathrm{APT}$ & - & - \\
\hline $\begin{array}{l}\text { Pediococcus } \\
\text { acidilactici }\end{array}$ & PAC-1.0 & Unknown & $30{ }^{\circ} \mathrm{C}, \mathrm{APT}$ & - & - \\
\hline $\begin{array}{l}\text { Carnobacterium } \\
\text { maltaromaticum }\end{array}$ & $\begin{array}{l}\text { DSM } \\
20730\end{array}$ & $\begin{array}{l}\text { Seafood } \\
\text { (rainbow trout) }\end{array}$ & $30{ }^{\circ} \mathrm{C}, \mathrm{APT}$ & - & - \\
\hline $\begin{array}{l}\text { Carnobacterium } \\
\text { divergens }\end{array}$ & $\begin{array}{l}\text { MAAE } \\
3.3\end{array}$ & Seafood (shrimps) & $30{ }^{\circ} \mathrm{C}, \mathrm{APT}$ & - & - \\
\hline $\begin{array}{l}\text { Enterococcus } \\
\text { faecalis }\end{array}$ & ESB 05 & $\begin{array}{l}\text { Seafood } \\
\text { (smoked salmon) }\end{array}$ & $30{ }^{\circ} \mathrm{C}, \mathrm{APT}$ & + & + \\
\hline $\begin{array}{l}\text { Enterococcus } \\
\text { faecalis }\end{array}$ & $\begin{array}{l}\text { ATCC } \\
29212\end{array}$ & Urine & $30{ }^{\circ} \mathrm{C}, \mathrm{APT}$ & + & + \\
\hline $\begin{array}{l}\text { Enterococcus } \\
\text { faecium }\end{array}$ & ESB 82 & Cheese & $30^{\circ} \mathrm{C}, \mathrm{APT}$ & - & - \\
\hline $\begin{array}{l}\text { Lactobacillus brevis } \\
\text { gravensis }\end{array}$ & $\begin{array}{l}\text { LMG } \\
7934\end{array}$ & Wine & $30{ }^{\circ} \mathrm{C}, \mathrm{APT}$ & + & + \\
\hline $\begin{array}{l}\text { Lactobacillus } \\
\text { curvatus }\end{array}$ & ESB 114 & Cheese & $30{ }^{\circ} \mathrm{C}, \mathrm{APT}$ & + & + \\
\hline $\begin{array}{c}\text { Lactobacillus } \\
\text { curvatus }\end{array}$ & MF 411 & Pork loin & $30{ }^{\circ} \mathrm{C}, \mathrm{APT}$ & - & - \\
\hline
\end{tabular}


Table 1 (continued)

\begin{tabular}{|c|c|c|c|c|c|}
\hline $\begin{array}{l}\text { Indicator } \\
\text { organism }\end{array}$ & Strain & Source & $\begin{array}{l}\text { Growth } \\
\text { media and } \\
\text { temperature }\end{array}$ & $\begin{array}{l}\text { E. } \\
\text { faecium } \\
\text { ALP7 }\end{array}$ & $\begin{array}{l}P . \\
\text { pentosaceus } \\
\text { ALP57 }\end{array}$ \\
\hline $\begin{array}{l}\text { Lactobacillus } \\
\text { curvatus }\end{array}$ & MF 368 & Pork loin & $30^{\circ} \mathrm{C}, \mathrm{APT}$ & + & + \\
\hline $\begin{array}{l}\text { Lactobacillus } \\
\text { curvatus }\end{array}$ & MF 379 & Pork loin & $30^{\circ} \mathrm{C}, \mathrm{APT}$ & - & - \\
\hline Lactobacillus sakei & MF 473 & "Servelat" ** & $30^{\circ} \mathrm{C}, \mathrm{APT}$ & + & + \\
\hline $\begin{array}{l}\text { Lactococcus lactis } \\
\text { subsp lactis }\end{array}$ & $\begin{array}{l}\text { ATCC } \\
11454\end{array}$ & Unknown & $30{ }^{\circ} \mathrm{C}, \mathrm{APT}$ & - & - \\
\hline Lactococcus lactis & ESB 533 & Meat & $30{ }^{\circ} \mathrm{C}, \mathrm{APT}$ & + & + \\
\hline $\begin{array}{l}\text { Lactobacillus } \\
\text { plantarum }\end{array}$ & ESB 1752 & Meat & $30{ }^{\circ} \mathrm{C}, \mathrm{APT}$ & - & - \\
\hline $\begin{array}{r}\text { Lactobacillus } \\
\text { plantarum }\end{array}$ & $\begin{array}{l}\text { CETC } \\
305\end{array}$ & Unknown & $30{ }^{\circ} \mathrm{C}, \mathrm{APT}$ & + & + \\
\hline $\begin{array}{l}\text { Lactobacillus } \\
\text { rhamnosus }\end{array}$ & ESB78 & "Alheira" & $30{ }^{\circ} \mathrm{C}, \mathrm{APT}$ & - & - \\
\hline $\begin{array}{l}\text { Lactobacillus } \\
\text { rhamnosus }\end{array}$ & ESB50 & "Alheira" & $30^{\circ} \mathrm{C}, \mathrm{APT}$ & - & - \\
\hline Lactobacillus sakei & MF 1186 & $\begin{array}{l}\text { Seafood } \\
\text { (smoked salmon) }\end{array}$ & $30^{\circ} \mathrm{C}, \mathrm{APT}$ & + & + \\
\hline Lactobacillus sakei & Lb 706 & Fresh beef meat & $30^{\circ} \mathrm{C}, \mathrm{APT}$ & + & + \\
\hline Lactobacillus sakei & $\begin{array}{l}\text { CETC } \\
494\end{array}$ & Unknown & $30{ }^{\circ} \mathrm{C}, \mathrm{APT}$ & - & - \\
\hline Lactobacillus sakei & ESB 256 & “Alheira” & $30{ }^{\circ} \mathrm{C}, \mathrm{APT}$ & - & - \\
\hline Lactobacillus sakei & MF 468 & "Servelat" & $30^{\circ} \mathrm{C}, \mathrm{APT}$ & + & + \\
\hline $\begin{array}{l}\text { Leuconostoc } \\
\text { mesenteroides }\end{array}$ & ESB 882 & Meat & $30^{\circ} \mathrm{C}, \mathrm{APT}$ & ++ & + \\
\hline
\end{tabular}

-, no zone of inhibition; +, $1 \mathrm{~mm}<$ zone $<5 \mathrm{~mm}$; ++, $5 \mathrm{~mm}<$ zone $<10 \mathrm{~mm}$; +++, zone $>10 \mathrm{~mm}$. In brackets, inhibition results after 6 months at $4{ }^{\circ} \mathrm{C}$. * Portuguese traditional fermented sausage generally made from pork meat, poultry, wheat bread, olive oil and spices. ${ }^{* *}$ Norwegian Bologna type sausage, made from beef and pork meat. MF - Matforsk, Norwegian Food Research Institute, Ås, Norway; ESB - Universidade Católica Portuguesa, Escola Superior de Biotecnologia, Porto, Portugal; NCTC - National Collection of Type Cultures, Central Public Health Laboratory Service, London, UK; ATCC - American Type Culture Collection, Manassas, VA, USA; LMG - Laboratorium voor Microbiologie, Universiteit Gent, Gent, Belgium; CETC - Spanish Type Culture Collection, Valencia, Spain.

by PCR with genus- and species-specific primers. The following primers were used: Enterococcus spp, EntF: 5'-TAC TGA CAA ACC ATT CAT GAT G-3' and EntR: 5'-AAC TTC GTC ACC AAC GCG AAC-3' (Ke et al., 1999); Pediococcus pentosaceus, PpeF: 5'-CGA ACT TCC GTT AAT TGA TCA G-3' and PuR: 5'-ACC TTG CGG TCG TAC TCC-3' (Mora et al., 1997), and Pediococcus acidilactici, PacF: 5'-CGA ACT TCC GTT AAT TGA TTA T-3' and PuR: 5'-ACC TTG CGG TCG TAC TCC-3' (Mora et al., 1997); each primer was acquired from Amersham, Bioscience, UK Limited (Buckinghamshire, UK). A 100 bp DNA ladder (Bio-Rad Laboratories, Richmond, CA) was used as molecular weight marker. Reference strains of pediococci and enterococci were used as positive controls (described in Section 2.1) and samples without genomic DNA were used as negative controls. 16S rDNA sequencing was also used to confirm identification since one of the strains was identified only to the genus level. Amplification of the $16 \mathrm{~S}$ rDNA was carried out with the primers 27F (AGA GTT TGA TCC TGG CTC AGG) and 1492R (GGT TAC CTT GTT ACG ACT T) using the following temperature profile: primary DNA denaturation step at $95{ }^{\circ} \mathrm{C}$ for $5 \mathrm{~min}$, followed by 30 cycles of $1 \mathrm{~min}$ at $94^{\circ} \mathrm{C}, 1 \mathrm{~min}$ at $55^{\circ} \mathrm{C}$, and $1.5 \mathrm{~min}$ at $72^{\circ} \mathrm{C}$, with an extension of the amplified product at $72{ }^{\circ} \mathrm{C}$ for $10 \mathrm{~min}$. Amplification reactions were performed in a MyCycler Thermal Cycler System (Bio-Rad). Following amplification, $5 \mu$ of product was separated at $90 \mathrm{~V}$ for $50 \mathrm{~min}$ in a $1 \%(\mathrm{w} / \mathrm{v})$ agarose gel in $1 \times$ TAE buffer (4.84 $\mathrm{g}$ Tris-base, $1.09 \mathrm{~g}$ glacial acetic acid, $0.29 \mathrm{~g}$ ethylenediaminetetraacetic acid, 11 distilled water), and then stained with $0.5 \mu \mathrm{g} / \mathrm{ml}$ of ethidium bromide. A 1-kb ladder molecular weight marker (Bio-Rad) was used. PCR products, used as templates, were previously purified with the GFX PCR DNA and Band Purification kit (GE HealthCare, Amersham Biosciences, Amersham, UK) and sent to STABVIDA (Lisbon, Portugal) for sequencing. On-line similarity searches were performed with the BLAST program in GenBank (http://www.ncbi.nlm.nih.gov).

\section{Screening for bacteriocinogenic activiry}

The detection of antimicrobial activity of strains ALP7 and ALP57 was performed according to the method described by Van Reenen et al. (1998) against several indicator microorganisms, some of them also isolated from seafood (Table 1). Antimicrobial activity was expressed as arbitrary units (AU) per $\mathrm{ml}$. One AU is defined as the reciprocal of the highest dilution showing a clear zone of growth inhibition (Van Reenen et al., 1998).

In a separate experiment, the cell-free supernatants (CFS) were preserved at $4{ }^{\circ} \mathrm{C}$ over a period of 6 months and evaluated regarding the bacteriocinogenic activity against $L$. monocytogenes.

\section{Growth and bacteriocin production}

For each strain, an overnight culture was inoculated $(1 \% \mathrm{v} / \mathrm{v})$ into $100 \mathrm{ml}$ of APT broth and incubated at $30^{\circ} \mathrm{C}$. Samples were taken every hour during $24 \mathrm{~h}$, and the changes in $\mathrm{pH}$ and optical density $(600 \mathrm{~nm})$ were recorded. Bacteriocin activity $(\mathrm{AU} / \mathrm{ml})$ in the $\mathrm{CFS}$ was recorded every 3 h, as described by Van Reenen et al. (1998), testing against two strains, namely, L. monocytogenes ESB54 and L. innocua 2030c (Central Public Health Laboratory, Colindale, London).

\section{Mode of action}

Twenty $\mathrm{ml}$ of each bacteriocin-containing CFS previously filtersterilized, were added to $150 \mathrm{ml}$ of early exponential phase cultures $\left(\approx 10^{6} \mathrm{cfu} / \mathrm{ml}\right)$ of $L$. monocytogenes ESB54 $(4 \mathrm{~h})$ and L. innocua $2030 \mathrm{c}$ $(5 \mathrm{~h})$. Optical density readings at $600 \mathrm{~nm}$ of target strains were determined every hour during 12 h. L. monocytogenes ESB54 and L. innocua 2030c cultures without added bacteriocins were used as controls.

Effects of enzymes, chemicals, $\mathrm{pH}$ and temperature on activity of bacteriocins

Cultures were grown in APT broth for $18 \mathrm{~h}$ at $30{ }^{\circ} \mathrm{C}$ followed by centrifugation $\left(10,000 \times \mathrm{g}, 10 \mathrm{~min}, 4^{\circ} \mathrm{C}\right)$ and $\mathrm{pH}$ adjustment of the CFS to $\mathrm{pH} 6.0$ with $1 \mathrm{M} \mathrm{NaOH}$. To test the sensitivity to the enzymes, $1 \mathrm{ml}$ of the CFS was incubated for $2 \mathrm{~h}$ at $30^{\circ} \mathrm{C}$ in the presence of proteinase $\mathrm{K}$, pronase E, papain, pepsin (Boehringer Mannheim $\mathrm{GmbH}$, Germany), lipase and $\alpha$-amylase (Sigma) at enzyme concentrations of $1 \mathrm{mg} / \mathrm{ml}$ and $0.1 \mathrm{mg} / \mathrm{ml}$. Also, $1 \%(\mathrm{w} / \mathrm{v}$ ) of sodium dodecyl sulphate (SDS), Tween 20, Tween 80, urea, Triton X-110, ox-bile and $\mathrm{NaCl}$ were added to the supernatants. EDTA was added to CFS to yield final concentrations of $0.1,2.0$ and $5.0 \mathrm{mM}$. Untreated CFS and detergents at these respective concentrations in water were used as controls. All samples were incubated at $30{ }^{\circ} \mathrm{C}$ for $5 \mathrm{~h}$.

The effect of $\mathrm{pH}$ on the activity of bacteriocins was tested by adjusting CFS from $\mathrm{pH} 2.0$ to 12.0 (at increments of two $\mathrm{pH}$ units) with sterile $1 \mathrm{M} \mathrm{NaOH}$ or $1 \mathrm{M} \mathrm{HCl}$. After $1 \mathrm{~h}$ of incubation at room temperature $\left(25^{\circ} \mathrm{C}\right)$, the samples were re-adjusted to $\mathrm{pH} 6.5$ with sterile $1 \mathrm{M} \mathrm{NaOH}$ or $1 \mathrm{M} \mathrm{HCl}$ as appropriate, and tested for antimicrobial activity. The effect of temperature on the bacteriocins activity was tested by incubating the CFS, adjusted to $\mathrm{pH} 6.5$ at 4, 10, 25, 30, 37, 60, 80 and $100{ }^{\circ} \mathrm{C}$ for $120 \mathrm{~min}$, except for $121{ }^{\circ} \mathrm{C}$ (20 min). The antimicrobial activity of the CFS after these treatments was tested against the target strains as described by Van Reenen et al. (1998).

\section{Adsorption of bacteriocins to the producer cells}

Bacteriocin-producing cells were cultured at $30^{\circ} \mathrm{C}$ for $18 \mathrm{~h}$. The $\mathrm{pH}$ of the cultures was adjusted to 6.0 with $1 \mathrm{M} \mathrm{NaOH}$ to allow maximal adsorption of the bacteriocin to the producer cells, according to the method described by Yang et al. (1992). The cells were then harvested $\left(12,000 \times g, 15 \mathrm{~min}, 4^{\circ} \mathrm{C}\right)$ and washed with sterile $0.1 \mathrm{M}$ phosphate buffer ( $\mathrm{pH}$ 6.5). The pellet was re-suspended in $10 \mathrm{ml}$ of $100 \mathrm{mM} \mathrm{NaCl}$ 
A

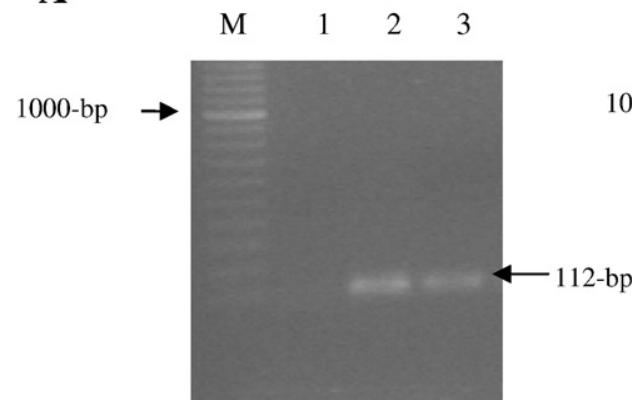

B

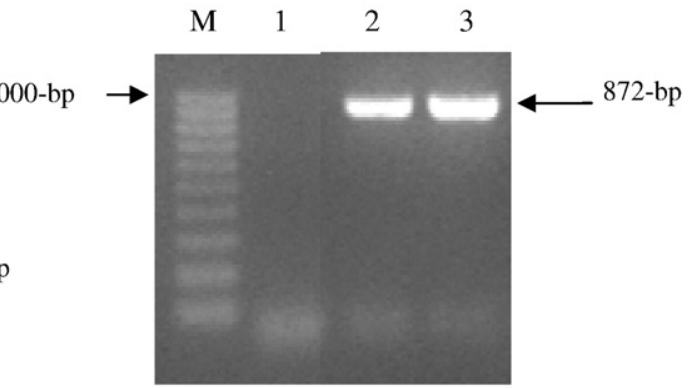

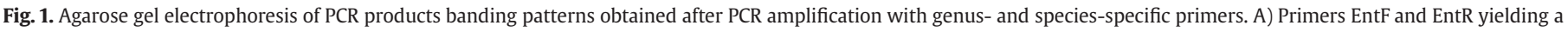

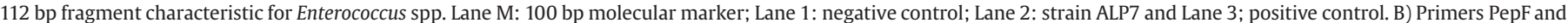

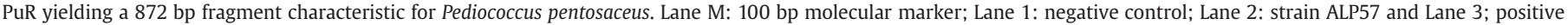
control.

( $\mathrm{pH} 2.0$ ) and stirred slowly for $1 \mathrm{~h}$ at $4{ }^{\circ} \mathrm{C}$. The suspension was then centrifuged $\left(12,000 \times \mathrm{g}, 15 \mathrm{~min}, 4^{\circ} \mathrm{C}\right)$, the CFS adjusted to $\mathrm{pH} 7.0$ with sterile $1 \mathrm{M} \mathrm{NaOH}$ and the bacteriocin activity tested as described above.

\section{Partial purification and molecular size of bacteriocins}

Strains ALP7 and ALP57 were inoculated ( $1 \% \mathrm{v} / \mathrm{v})$ into $400 \mathrm{ml}$ of APT broth, and incubated without agitation at $30{ }^{\circ} \mathrm{C}$ until early stationary phase $(18 \mathrm{~h})$ corresponding to maximum bacteriocin production. The cells were harvested $\left(12,000 \times g, 20 \mathrm{~min}, 4^{\circ} \mathrm{C}\right)$ and the peptides precipitated from the CFS with $40 \%, 60 \%$ and $80 \%$ saturated ammonium sulphate, gradually added by slow stirring during $4 \mathrm{~h}$ at $4{ }^{\circ} \mathrm{C}$, in independent experiments (Sambrook et al., 1989). Precipitated peptides in the pellet and floating on the surface were collected and resuspended in one-tenth volume $25 \mathrm{mM}$ ammonium acetate buffer (pH 6.5). The samples were stored at $-20^{\circ} \mathrm{C}$ for one week. Activity tests were performed according to the method previously described of Van Reenen et al. (1998).

For determination of bacteriocins molecular size, precipitated peptides re-suspended in $25 \mathrm{mM}$ ammonium acetate buffer ( $\mathrm{pH} 6.5$ ) were separated by Tricine-SDS-PAGE, as described by Schägger and Von Jagow (1987). A low molecular weight marker with sizes ranging from 2.5 to $45 \mathrm{kDa}$ (Amersham Pharmacia Biotech Europe GmbH, Freiburg, Germany) was used. After fixing the gels, one half was stained with Coomassie Brilliant Blue R250 (Bio-Rad). In order to determine the positions of the active peptide bands, the other half of the gel (not stained and extensively pre-washed with sterile distilled water) was overlaid with $2 \mathrm{ml}$ of $L$. monocytogenes ESB54 $\left(10^{6} \mathrm{cfu} / \mathrm{ml}\right)$ embedded in $0.7 \%(\mathrm{w} / \mathrm{v}) \mathrm{BHI}$ agar.

\section{PCR detection and sequencing of genes encoding bacteriocins}

DNA extraction was performed according to the method described by Dellaglio et al. (1973). The following primer sequences were used for pediocin PA-1, Pedpro: 5'-CAA GAT CGT TAA CCA GTT T-3' and Ped1041: 5'-CCG TTG TTC CCA TAG TCT AA-3' (Albano et al., 2007); and for enterocin B, 5'-GAA AAT GAT CAC AGA ATG CCT A-3' AND 5'-GTT GCA TTT AGA GTA TAC ATT TG-3' (Casaus et al., 1997) synthesised by Eurofins MWG Operon GmbH (Ebersberg, Germany). PCR reactions were performed using a MyCycler Thermal Cycler System (Bio-Rad). The PCR reactions were the following for pediocin PA-1: an initial

\section{A1}

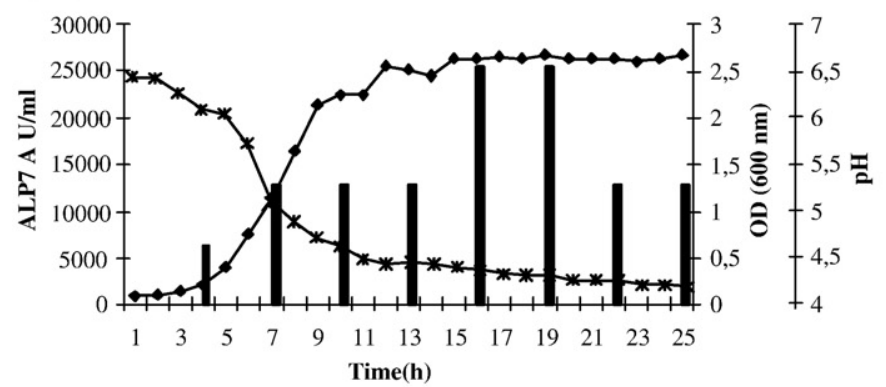

A2

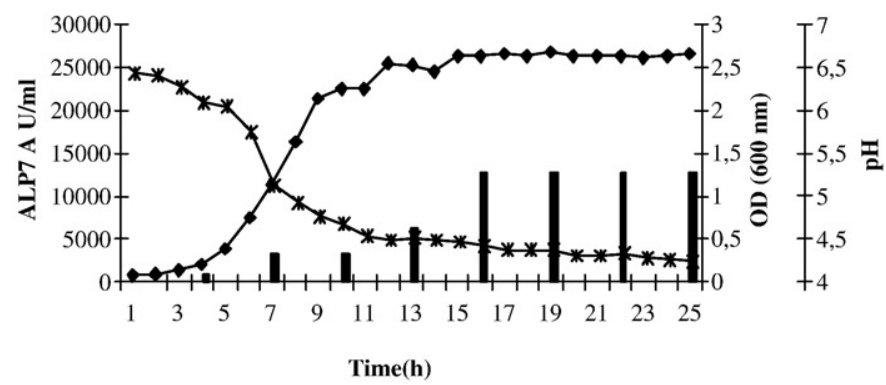

\section{B1}

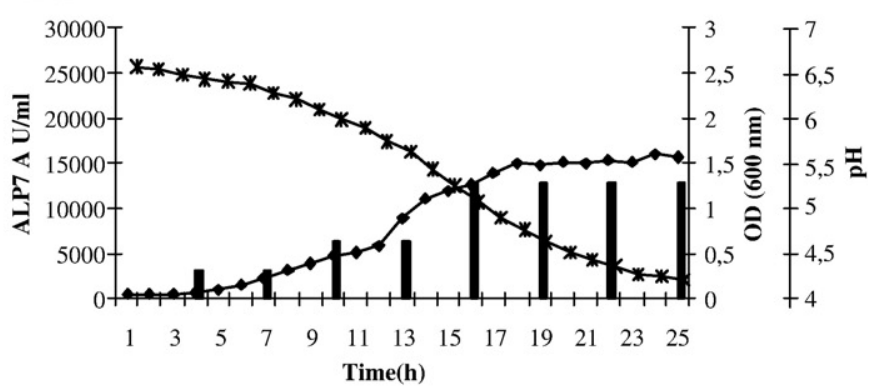

B2

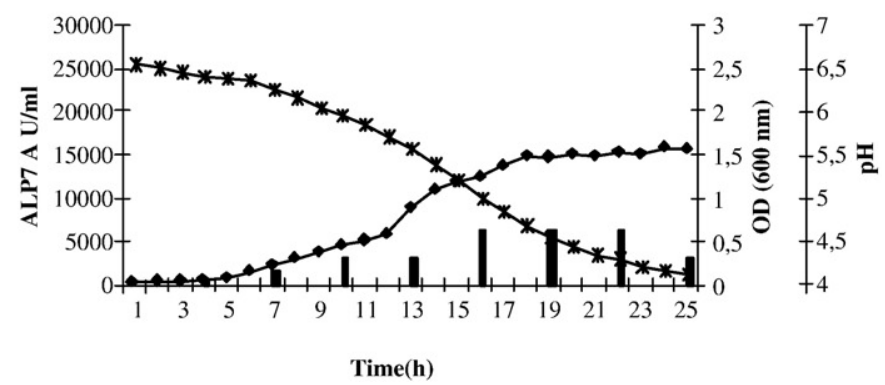

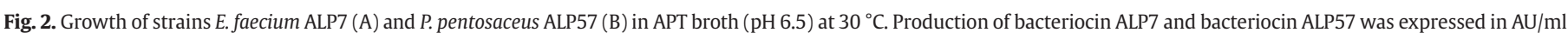
(bars) against L. monocytogenes ESB54 (A1 and B1) and L. innocua 2030c (A2 and B2). Optical density ( $\bullet$ ) and pH (*) are also indicated. 
denaturation step of $94^{\circ} \mathrm{C}$ for $1 \mathrm{~min}$, followed by 35 cycles of $1 \mathrm{~min}$ at $94{ }^{\circ} \mathrm{C}, 30 \mathrm{~s}$ at $50{ }^{\circ} \mathrm{C}$, and $1 \mathrm{~min}$ at $72{ }^{\circ} \mathrm{C}$, with a final extension at $72{ }^{\circ} \mathrm{C}$ for $5 \mathrm{~min}$; and for enterocin $\mathrm{B}$ : 5 min denaturation at $95{ }^{\circ} \mathrm{C}$; followed by 30 cycles of $30 \mathrm{~s}$ at $95{ }^{\circ} \mathrm{C}, 30 \mathrm{~s}$ at $56{ }^{\circ} \mathrm{C}$, and $30 \mathrm{~s}$ at $72{ }^{\circ} \mathrm{C}$; this followed by $5 \mathrm{~min}$ at $72{ }^{\circ} \mathrm{C}$ and a cool down to $4{ }^{\circ} \mathrm{C}$ (Strompfová et al., 2008). The amplified products were visualized in a $1 \%(\mathrm{w} / \mathrm{v})$ agarose gel stained with $0.5 \mu \mathrm{g} / \mathrm{ml}$ of ethidium bromide (Sigma) and visualized by UV light. A 1-kb ladder molecular weight marker (Bio-Rad) was used. Strains P. acidilactici HA-6111-2 and E. faecium ESB 48 were used as the positive control strains. For each strain, the band corresponding to the correct size was purified from the gel using the GFX PCR DNA and Band Purification kit (GE HealthCare, Amersham Biosciences, Amersham, UK) and sent to STABVIDA (Lisbon, Portugal) for sequencing. On-line similarity searches were performed with the BLAST program in GenBank (http://www.ncbi.nlm.nih.gov).

\section{Results}

\section{Identification of bacteriocin-producing strains}

The strain ALP7 was identified as Enterococcus spp. based on positive Gram-reaction, absence of catalase, morphology (cocci in pairs) and genus-specific PCR yielding a 112 bp fragment (Fig. 1A). Further identification to species level, E. faecium, was based on $16 \mathrm{~S}$
rDNA sequencing. Strain ALP57 was identified as Pediococcus pentosaceus by physiological and biochemical characteristics namely, Gramreaction (positive), absence of catalase and cell morphology (tetrads) and confirmed by PCR with species-specific primers yielding a $872 \mathrm{bp}$ fragment characteristic for the species (Fig. 1B). The sequence data of rDNA for ALP7 and ALP57 exhibited 99\% and 100\% similarities to the 16S rDNA sequences of $E$. faecium (accession no. DQ672262) and $P$. pentosaceus (accession no. CP000422). Both strains showed carbohydrate fermentation reactions characteristic for the species (data not shown).

\section{Antimicrobial activity screening}

With the exception of Gram-negative strains, E. faecium ALP7 and P. pentosaceus ALP57 CFS demonstrated antagonistic activity against the majority of the indicator organisms investigated. Greater inhibition was observed against $L$. monocytogenes and L. innocua strains in comparison with the remaining indicators (Table 1 ).

\section{Growth and bacteriocin production}

During the $24 \mathrm{~h}$ of growth at $30{ }^{\circ} \mathrm{C}$, the $\mathrm{pH}$ of both cultures decreased from 6.5 to 4.3 (E. faecium ALP7) and from 6.4 to 4.1 (P. pentosaceus ALP57) (Fig. 2). Detectable levels of the bacteriocins

A

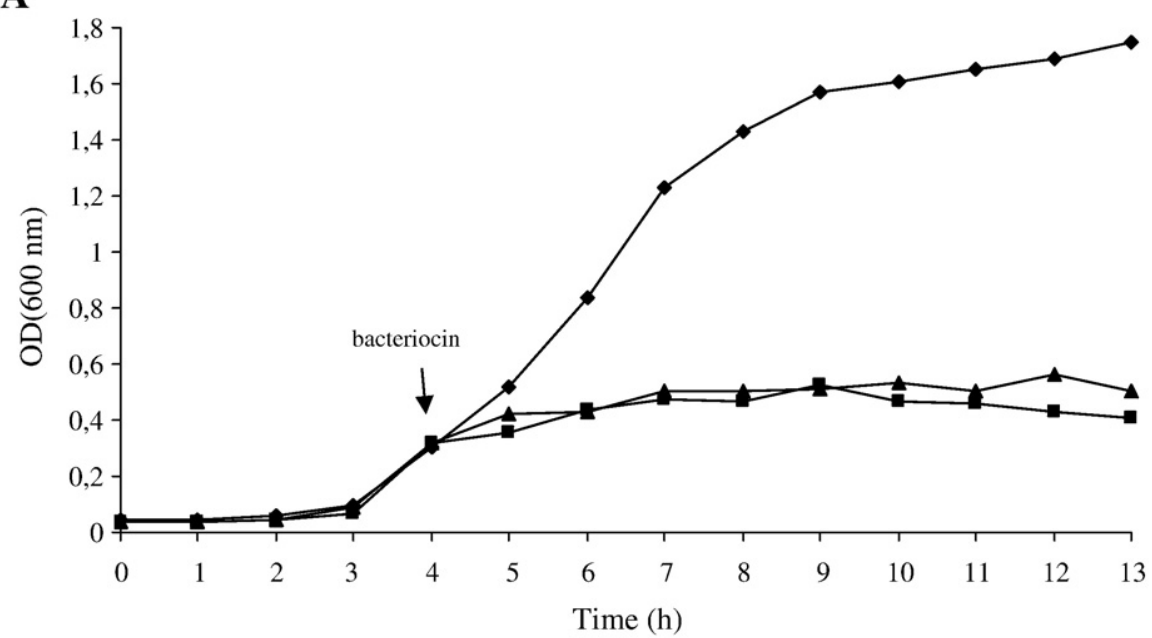

B

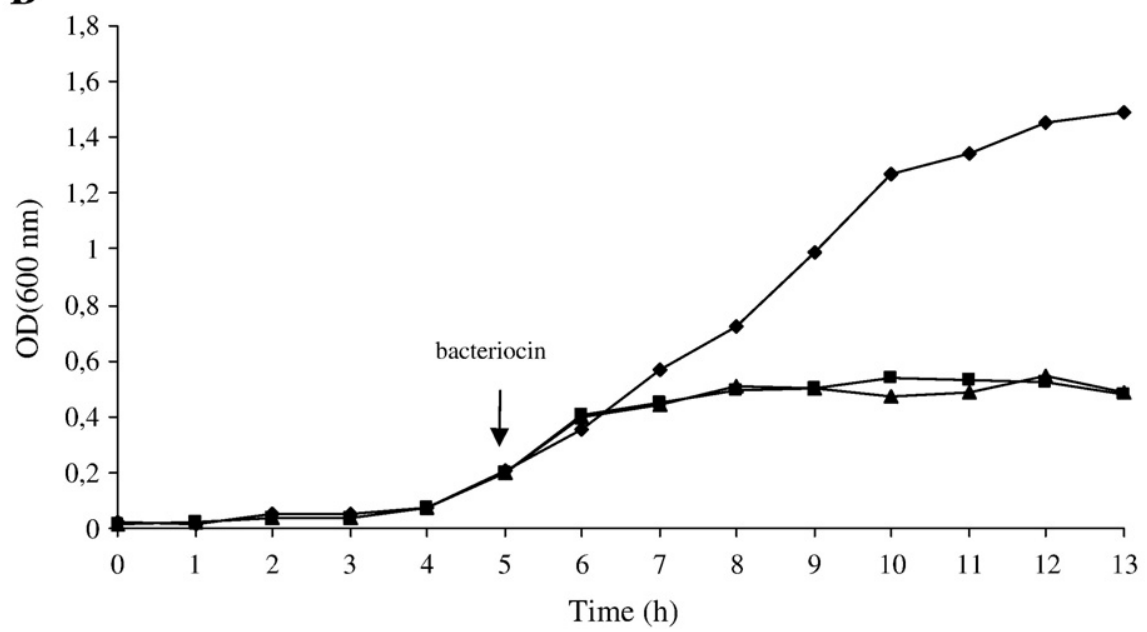

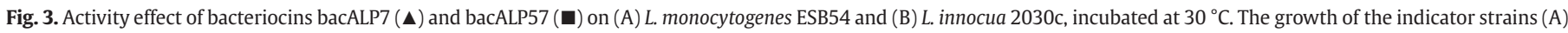

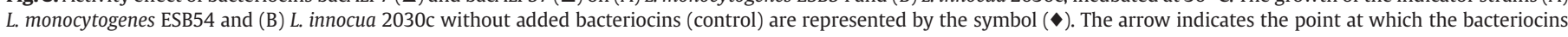
were added. 
were recorded after $4 \mathrm{~h}$ of growth (approximately $6400 \mathrm{AU} / \mathrm{ml}$ and $3200 \mathrm{AU} / \mathrm{ml}$ against L. monocytogenes ESB54). Maximum production of bacALP7 (25,600 AU/ml against L. monocytogenes ESB54) was reached after $16 \mathrm{~h}$ at $\mathrm{pH} 4.4$, in the beginning of the stationary phase (Fig. 2A1), followed by a decrease to $12,800 \mathrm{AU} / \mathrm{ml}$ after $21 \mathrm{~h}$ of incubation. Maximum activity yield against L. innocua 2030c was also observed at $16 \mathrm{~h}$ of growth, $\mathrm{pH} 4.5(12,800 \mathrm{AU} / \mathrm{ml})$ remaining stable as observed in Fig. 2A2. P. pentosaceus ALP57 exhibited maximum activity $(12,800 \mathrm{AU} / \mathrm{ml})$ against $L$. monocytogenes ESB54 (Fig. 2B1) and $6400 \mathrm{AU} / \mathrm{ml}$ against L. innocua 2030c (pH 4.8) both at the end of exponential phase. In this case, a decrease of bacteriocin activity to $3200 \mathrm{AU} / \mathrm{ml}$ was recorded at the end of stationary phase (Fig. 2B2). Activity of both bacteriocinogenic CFSs was maintained against $L$. monocytogenes ESB54 during storage at refrigeration temperature $\left(4{ }^{\circ} \mathrm{C}\right)$ up to 6 months (data not shown).

\section{Mode of action}

Addition of bacALP7 (25,600 AU/ml) and bacALP57 (12,800 AU/ml) to

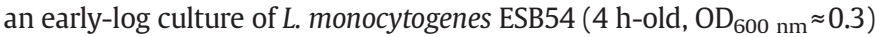
repressed pathogen growth for $9 \mathrm{~h}$ (Fig. 3A). Addition of bacALP7 $(12,800 \mathrm{AU} / \mathrm{ml})$ and bacALP57 $(6400 \mathrm{AU} / \mathrm{ml})$ to an early-log culture of $L$. innocua $2030 \mathrm{c}\left(5 \mathrm{~h}\right.$-old, $\left.\mathrm{OD}_{600 \mathrm{~nm}} \approx 0.2\right)$ repressed cell growth in a similar way (Fig. 3B). Both bacteriocins demonstrated a bacteriostatic mode of action towards the Listeria strains. In the untreated (control) samples, no repression or inhibition of growth was observed.

Effects of chemicals, enzymes, temperature and $\mathrm{pH}$ on activity of bacteriocins

Both bacteriocins were completely inactivated after treatment with the proteolytic enzymes trypsin, proteinase $\mathrm{K}$, pronase $\mathrm{E}$ and papain (Table 2). BacALP7 was completely inactivated by pepsin at $1 \mathrm{mg} / \mathrm{ml}$ but only partially at a concentration of $0.1 \mathrm{mg} / \mathrm{ml}$. Activity of bacALP57 was reduced at both concentrations. The exposure of bacteriocins to different $\mathrm{pH}$ values showed that both remained fully active in the $\mathrm{pH}$ range of 2.0-8.0, and also at pH 10.0 in the case of P. pentosaceus ALP57. Reduced activity of both bacteriocins was found after treatment at $\mathrm{pH}$ 12.0 (Table 2). At higher temperatures, both bacteriocins revealed some degree of resistance, maintaining $50 \%$ of the activity when subjected to $121^{\circ} \mathrm{C}$ for $20 \mathrm{~min}$. P. pentosaceus ALP57 maintained stability at low temperatures, including at $4{ }^{\circ} \mathrm{C}$, in contrast to E. faecium ALP7 which showed a partial loss of activity. Both bacteriocins remained stable when treated with $1 \%(\mathrm{w} / \mathrm{v})$ of $\mathrm{NaCl}$, SDS, Triton X-100, Tween 20 , Tween 80 and EDTA $(0.1 \mathrm{mM}, 2 \mathrm{mM}$ and $5 \mathrm{mM})$. However, the antimicrobial activity was affected after treatment with Ox-bile $(1 \% \mathrm{w} / \mathrm{v})$. The addition of urea to both bacteriocins did not reduce the antimicrobial activity against $L$. monocytogenes ESB54 in contrast to the effect produced on L. innocua 2030c. Overall, L. innocua 2030c appear to be less sensitive to both bacteriocins after treatments (Table 2 ).

\section{Adsorption of bacteriocins to the producer cells}

The loss of bacteriocin activity after the treatment of strains ALP7 and ALP57 with $100 \mathrm{mM} \mathrm{NaCl}$ at pH 2.0 suggested that the bacteriocins did not adhere to the producer cells (data not shown).

\section{Partial purification and molecular size of bacteriocins}

The bacteriocins bacALP7 and bacALP57 were isolated from 18-h-old cultures in APT medium. The bacteriocins were concentrated by precipitation with $60 \%(\mathrm{w} / \mathrm{v})$ ammonium sulphate. After precipitation, the inhibitory activity of both bacteriocins against L. monocytogenes ESB54 showed a slight increase $(\approx 10 \%)$.

The analysis by Tricine-SDS-PAGE gel electrophoresis showed peptide bands for bacALP7 and bacALP57 below $6.5 \mathrm{kDa}$ in size (Fig. 4).
Table 2

Effect of different treatments on the activity of bacteriocins E. faecium ALP7 and P. pentosaceus ALP57 against the target organisms L. monocytogenes ESB54 and L. innocua 2030c, expressed in arbitrary units (AU/ml) and corresponding percentage values (\%)

\begin{tabular}{|c|c|c|c|c|}
\hline \multirow[t]{4}{*}{ Treatment } & \multirow{2}{*}{\multicolumn{2}{|c|}{$\begin{array}{l}\text { Bacteriocin activity of } E \text {. } \\
\text { faecium ALP7 } \\
\mathrm{AU} / \mathrm{ml}(\%)\end{array}$}} & \multirow{2}{*}{\multicolumn{2}{|c|}{$\begin{array}{l}\text { Bacteriocin activity of } P \text {. } \\
\text { pentosaceus ALP57 } \\
\mathrm{AU} / \mathrm{ml}(\%)\end{array}$}} \\
\hline & & & & \\
\hline & L. monocytogenes & L. innocua & L. monocytogenes & L. innocua \\
\hline & ESB54 & $2030 c$ & ESB54 & $2030 c$ \\
\hline $\begin{array}{l}\text { Without } \\
\text { treatment }\end{array}$ & $25,600(100 \%)$ & $12,800(100 \%)$ & $12,800(100 \%)$ & $6400(100 \%)$ \\
\hline \multicolumn{5}{|c|}{ Treatment with $1 \%$} \\
\hline $\begin{array}{l}\text { NaCl, SDS, } \\
\text { Triton X-100, } \\
\text { Tween 20, } \\
\text { Tween } 80\end{array}$ & $25,600(100 \%)$ & $12,800(100 \%)$ & $12,800(100 \%)$ & $6400(100 \%)$ \\
\hline Urea & $25,600(100 \%)$ & $800(6.25 \%)$ & $12,800(100 \%)$ & $3200(50 \%)$ \\
\hline Ox-bile & $3200(12.5 \%)$ & $400(3.125 \%)$ & $400(3.125 \%)$ & $200(3.25 \%)$ \\
\hline
\end{tabular}

EDTA

$0.1 \mathrm{mM}$,
$2 \mathrm{mM}$,
$5 \mathrm{mM}$

Effect of enzymes $(0.1 \mathrm{mg} / \mathrm{ml} / 1 \mathrm{mg} / \mathrm{ml})$

$\begin{array}{llll}\text { Proteinase } \mathrm{K}, & 0 & 0 & 0\end{array}$

Pronase $\mathrm{E}$

Papain

Lipase

$\begin{array}{lllll}\alpha \text {-Amylase } & 25,600(100 \%) & 12,800(100 \%) & 12,800(100 \%) & 6400(100 \%) \\ \text { Pepsin } & 3200(12.5 \%) / 0 & 0 & 3200(25 \%) / 400 & 1600(25 \%)) / 0\end{array}$

$25,600(100 \%)$

$12,800(100 \%) \quad 12,800(100 \%)$

$6400(100 \%)$

$\begin{array}{lllll}\alpha \text {-Amylase } & 25,600(100 \%) & 12,800(100 \%) & 12,800(100 \%) & 6400(100 \%) \\ \text { Pepsin } & 3200(12.5 \%) / 0 & 0 & 3200(25 \%) / 400 & 1600(25 \%)) / 0\end{array}$ (3.25\%)

$\begin{array}{lllll}\text { Effect of temperature }\left({ }^{\circ} \mathrm{C}\right) \text { after } 2 \mathrm{~h} & & & \\ 4 & 6400(25 \%) & 1600(12.5 \%) & 12,800(100 \%) & 3200(50 \%) \\ 10 & 12,800(50 \%) & 1600(12.5 \%) & 12,800(100 \%) & 6400(100 \%) \\ 25 & 25,600(100 \%) & 3200(25 \%) & 12,800(100 \%) & 3200(50 \%) \\ 30,37 & 25,600(100 \%) & 3200(25 \%) & 12,800(100 \%) & 1600(25 \%) \\ 60 & 6400(25 \%) & 3200(25 \%) & 3200(25 \%) & 800(12.5 \%) \\ 80 & 12,800(50 \%) & 3200(25 \%) & 9600(75 \%) & 1600(25 \%) \\ 100,121 & 12,800(50 \%) & 1600(12.5 \%) & 6400(50 \%) & 1600(25 \%)\end{array}$

(20 $\mathrm{min})$

Effect of $\mathrm{pH}$ after $1 \mathrm{~h}$

\begin{tabular}{lllll}
2 & $25,600(100 \%)$ & $1600(12.5 \%)$ & $12,800(100 \%)$ & $1600(25 \%)$ \\
4,6 & $25,600(100 \%)$ & $12,800(100 \%)$ & $12,800(100 \%)$ & $3200(50 \%)$ \\
8 & $25,600(100 \%)$ & $1600(12.5 \%)$ & $12,800(100 \%)$ & $1600(25 \%)$ \\
10 & $12,800(50 \%)$ & $800(6.25 \%)$ & $12,800(100 \%)$ & $1600(50 \%)$ \\
12 & $6400(25 \%)$ & $400(3.125 \%)$ & $1600(12.5 \%)$ & $400(6.25 \%)$ \\
\hline
\end{tabular}

PCR detection and sequencing of genes encoding bacteriocins

The amplification of DNA of strains ALP7 and ALP57 with specific primers for enterocin B and pediocin PA-1 yielded $360 \mathrm{~kb}$ and $1044 \mathrm{~kb}$ fragments, respectively (Fig. 5). The fragments revealed homology to enterocin B (GenBank Accession number U87997.1; Casaus et al., 1997) and pediocin PA-1 (GenBank Accession number AY316525; Miller et al., 2005). Bacteriocins bacALP7 and bacALP57 are thus considered similar to enterocin $\mathrm{B}$ and pediocin PA-1, respectively.

\section{Discussion}

The two bacteriocin-producing strains isolated from marine nonfermented shellfish were identified pheno- and geno-typically as $E$. faecium ALP7 and P. pentosaceus ALP57. Other studies, previously mentioned, also showed the occurrence of LAB in seafood products, although Carnobacterium spp. was the dominant genus in most studies. The inhibitory substances produced by both strains were inactivated by proteolytic enzymes (Table 2), confirming their proteinaceous nature and indicating the presence of bacteriocins (Todorov and Dicks, 2005). Moreover, their activities were not affected by lipolytic or glycolytic 

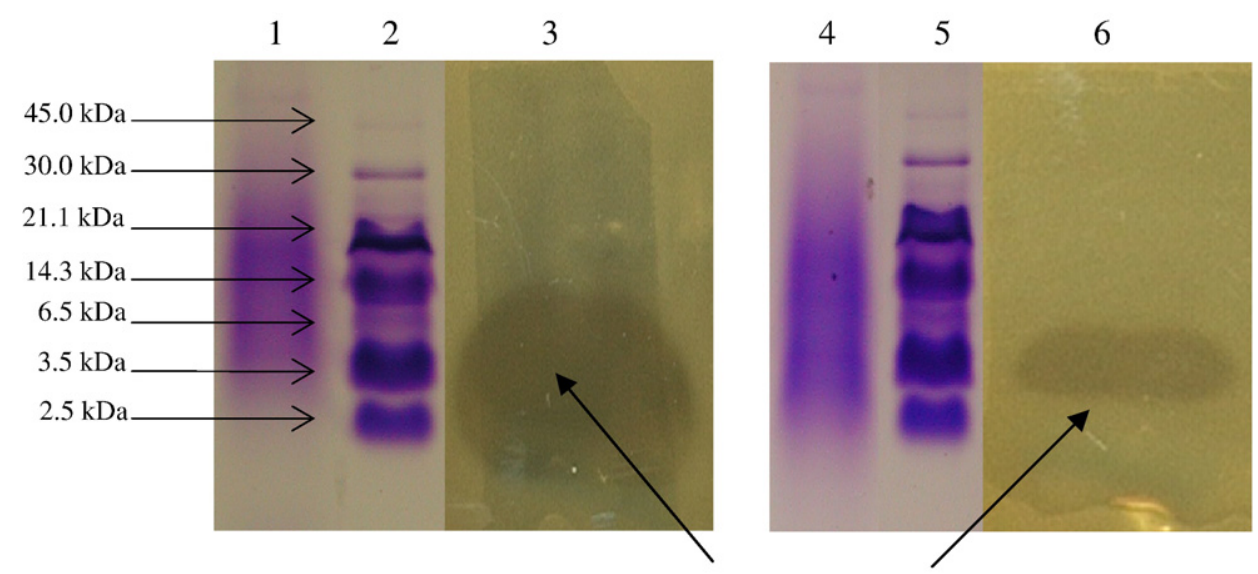

Inhibition zone against

L. monocytogenes ESB54

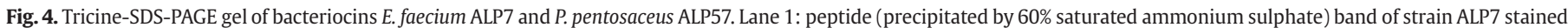

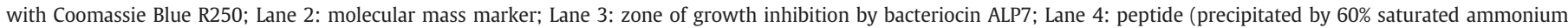

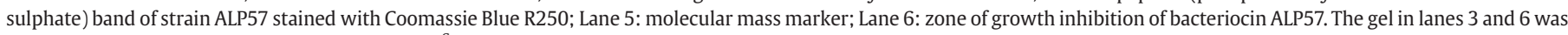
overlaid with L. monocytogenes ESB54 (approx. $10^{6} \mathrm{CFU} / \mathrm{ml}$ ), embedded in BHI agar, after incubation at $30{ }^{\circ} \mathrm{C}$ for $24 \mathrm{~h}$.

enzymes suggesting that the active moiety was not a lipid or a glucan, respectively (Tomé et al., 2006). The inhibitory effect was also enhanced at refrigeration temperatures particularly for P. pentosaceus ALP57. Like most of the described bacteriocins (e.g. Messi et al., 2001; Todorov and Dicks, 2005), the bacteriocins described in this study were also heat tolerant, despite the reduction in activity. In contrast, bacteriocin ST15, produced by E. mundtii, was inactivated after $10 \mathrm{~min}$ at $90-121{ }^{\circ} \mathrm{C}$ (De Kwaadsteniet et al., 2005). Treatments with $1 \% \mathrm{NaCl}$, Triton X-100, Tween 20, Tween 80, and EDTA did not affect the bacteriocins (Table 2) as reported similarly for enterocin EJ97, produced by E. faecalis (Gálvez et al., 1998), pediocin HA-6111-2 produced by P. acidilactici (Albano et al., 2007) and bacteriocin ST15 produced by E. mundtii (De Kwaasdsteniet et al., 2005). Other treatments, such as addition of ox-bile and urea (in the case of L. innocua 2030c) to the CFS, reduced the activity of the bacteriocins. In general, bacteriocins demonstrated higher activity against $L$. monocytogenes ESB54 after all treatments, in comparison with $L$. innocua 2030c. It would be interesting to further investigate the structural and functional changes of the bacteriocins induced by some treatments. This would help to understand the different behaviour observed for L. monocytogenes and L. innocua strains.

The antimicrobial spectra observed for E. faecium ALP7 and P. pentosaceus ALP57 included several genera indicating a broad spectrum of activity against Gram-positive organisms. A high level of inhibitory activity against $L$. monocytogenes was evident, including strains isolated from seafood. Strong antilisterial bacteriocins have been allocated to Class Ila (Nes et al., 2001). No activity was observed against the Gram-negative bacteria tested. Inhibition of Gram-negative bacteria is unusual, and has thus far only been reported for a few LAB bacteriocins (e.g. Messi et al., 2001; Todorov and Dicks, 2004; De Kwaadsteniet et al., 2005). The bacteriocinogenic activity of both bacteriocins against all $L$. monocytogenes strains, remained, although reduced, after 6 months at $4{ }^{\circ} \mathrm{C}$. Testing the strains' ability to survive and maintain the functionality at $-20^{\circ} \mathrm{C}$ for several months would be useful for an evaluation of their application as biopreservatives.

Like most bacteriocins (Pilet et al., 1995; Tahiri et al., 2004; Tomé et al., 2006), those investigated in the current study were secreted into the culture medium in the early exponential phase of growth. The detectable levels of the bacteriocins recorded after $4 \mathrm{~h}$ of growth could indicate that the peptide is a primary metabolite as reported for other bacteriocins produced by L. lactis subsp. lactis A164 (Cheigh et al., 2002), P. acidilactici (Nieto-Lozano et al., 2002), and E. mundtii ST15 (De Kwaadsteniet et al., 2005). An increase in the production during the log phase was observed for $E$. faecium ALP7, reaching their maximum concentration at the beginning of stationary phase. Then, a decrease in activity against $L$. monocytogenes ESB54 was observed from 25,600 to $12,800 \mathrm{AU} / \mathrm{ml}$ below $\mathrm{pH}$ 4.3. The biosynthesis of $P$. pentosaceus ALP57 bacteriocin was
A

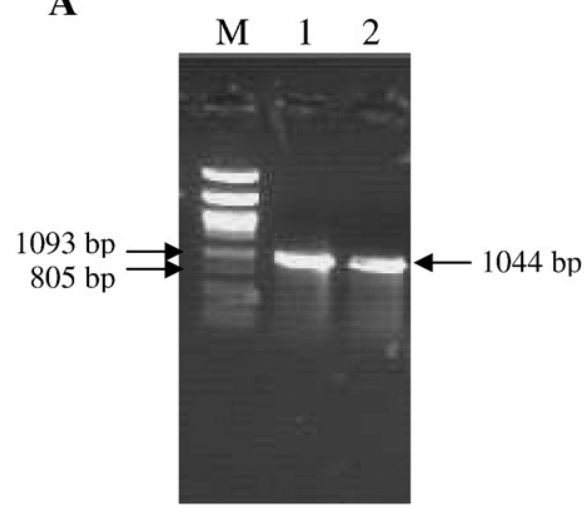

B

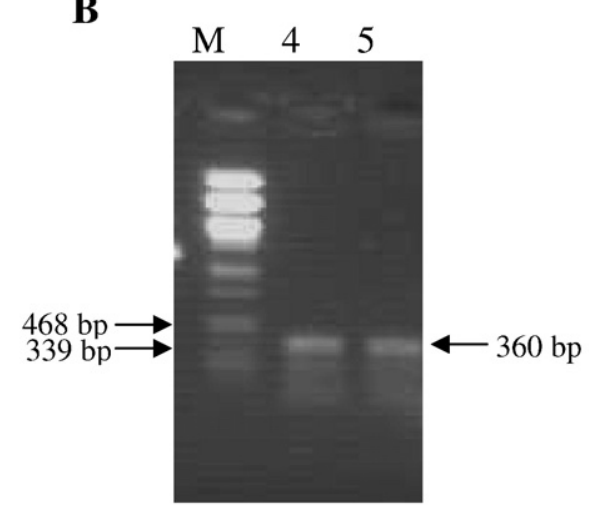

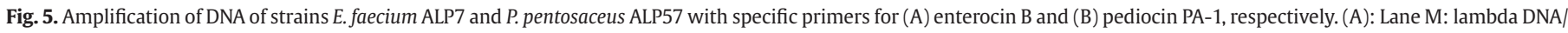

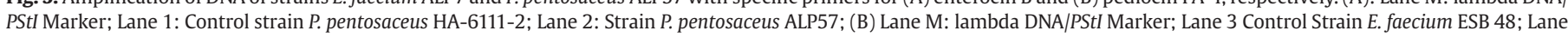
4: Strain E. faecium ALP7. 
maximal at the end of the exponential phase, in agreement with other studies (Yamazaki et al., 2003, Campos et al., 2006).

The bacteriocins revealed a bacteriostatic mode of action towards the target indicators. However, particularly in the case of L. innocua 2030c, a slow recovery of growth was observed for $2 \mathrm{~h}$ followed by stability in optical density units. As reported by Tomé et al. (2006), the time when a bacteriocin is added to a food system might influence significantly their mode of action on the target strain. The same authors reported that the addition of $P$. acidilactici ET34 at 5 h of growth of L. innocua 2030c had a bacteriostatic effect but, when added at the beginning or after just $3 \mathrm{~h}$ of incubation, the result would be a bactericidal activity on the target indicator.

More accurate techniques could be used to determine the molecular mass of molecules, yet the SDS-PAGE technique provides valuable information about the presence of the peptides (Moreno et al., 2002). The molecular weights of the bacteriocins were close to that reported for other small bacteriocins $(<10 \mathrm{kDa})$ produced by enterococci and pediococci, e.g., bacteriocin ST15 from E. mundtii (De Kwaadsteniet et al., 2005), bacteriocin ET05 from E. faecium and bacteriocin ET34 from P. acidilactici (Tomé et al., 2008). Partial purification of the produced bacteriocins was attempted as described by Yang et al. (1992). No adsorption of bacteriocins to their producer cells was observed, in concordance with other authors [e.g. Ivanova et al., 2000 (bozacin B14), Todorov and Dicks, 2005 (pediocin ST18); Albano et al., 2007 (pediocins HA-6111-2 and HA5692-3)] thus, the semi-purification was performed by peptides precipitation with 60\% ammonium sulphate (Sambrook et al., 1989) in subsequent experiments.

The bacteriocin produced by $P$. pentosaceus ALP57 showed similarity to pediocin PA-1/AcH (Miller et al., 2005), a so-called pediocinlike bacteriocin (class IIa; Nes et al., 2001). By other hand, the bacteriocin produced by E. faecium ALP7 demonstrated similarity with enterocin B (Casaus et al., 1997) a linear nonpediocin-like enterocin which belongs to the Class IIc (Klaenhammer, 1993) or Class II3 under the recent proposal by Frank et al. (2007). The pediocin PA-1/AcH was the first class IIa bacteriocin characterized and is extensively studied (Nieto-Lozano et al., 1992; Chen and Hoover, 2003). Synthesis initially was detected in P. acidilactici strains (Bhunia et al., 1988; Gonzalez and Kunka, 1987) but $P$. pentosaceus has also ability to produce pediocin $\mathrm{AcH}$ as recently described by Bagenda et al. (2008) in a marine fermented seafood product. Other pediocins have been associated to P. pentosaceus, including pediocin A (Fleming et al., 1975), pediocin N5p (Strasser de Saad and Manca de Nadra, 1993), pediocin P (Osmanağaoğlu et al., 2001), pediocin ACCEL (Wu et al., 2004), pediocin SM-1 (Anastasiadou et al., in press). In recent years, there have been numerous reports on bacteriocin-producing enterococci, primarily among E. faecium associated with food systems (Giraffa, 2003). Enterococcal bacteriocins (A, B, I and P) proved to be strong inhibitors of pathogens as L. monocytogenes (Ennahar et al., 2001). Enterocin B was firstly described by Casaus et al. (1997). Both pediocin PA-1/ACH and enterocin B have been tested as natural food preservatives in many food systems, particularly dairy and meat products (Drider et al., 2006) but neither of the bacteriocins have been used in seafoods. Other class Ila bacteriocins have been applied, for instance, divercin V41 (Duffes et al., 1999) and sakacin P (Katla et al., 2001) both to cold-smoked salmon, bavaricin A to brined shrimp (Einarsson and Lauzon, 1995), and piscicosin CS526 to surimi (Yamazaki et al., 2003).

To our knowledge this is the first report of a pediocin PA-1/AcH as well as enterocin $B$ isolated from marine non-fermented shellfish.

\section{Acknowledgements}

To Fundação para a Ciência e a Tecnologia for financial support by PhD fellowships for authors A. L. Pinto (SFRH/BD/8805/2002) and H. Albano (SFRH/BD/13161/2003).

\section{References}

Al-Holy, M., Ruiter, J., Lin, M., Kang, D.H., Rasco, B., 2004. Inactivation of Listeria innocua in nisin-treated salmon (Oncorhynchus keta) and sturgeon (Acipenser transmontanus) caviar heated by radio frequency. Journal of Food Protection 67, 1848-1854.

Albano, H., Todorov, S.D., van Reenen, C.A., Hogg, T., Dicks, L.M., Teixeira, P., 2007. Characterization of two bacteriocins produced by Pediococcus acidilactici isolated from "Alheira", a fermented sausage traditionally produced in Portugal. International Journal of Food Microbiology 116, 239-247.

Anastasiadou, S., Papagianni, M., Filiousis, G., Ambrosiadis, I., Koidis, P., in press. Growth and metabolism of a meat isolated strain of Pediococcus pentosaceus in submerged fermentation. Purification, characterization and properties of the produced pediocin SM-1. Enzyme and Microbial Technology doi:10.1016/j.enzmictec.2008.05.007

Bagenda, D.K., Hayashi, K., Yamazaki, K., Kawai, Y., 2008. Characterization of an antibacterial substance produced by Pediococcus pentosaceus Iz3.13 isolated from Japanese fermented marine food. Fisheries Science 74, 439-448.

Balcázar, J.L., de Blas, I., Ruiz-Zarzuela, I., Cunningham, D., Vendrell, D., Múzquiz, J.L., 2006. The role of probiotics in aquaculture. Veterinary Microbiology 114, 173-186.

Ben Embarek, P.K., 1994. Presence, detection and growth of Listeria monocytogenes in seafoods: a review. International Journal of Applied Bacteriology 68, 189-198.

Bhunia, A.K., Johnson, M.C., Ray, B., 1988. Purification, characterization and microbial spectrum of a bacteriocin produced by Pediococcus acidilactici. Journal of Applied Bacteriology 65, 261-268.

Brett, M.S.Y., Short, P., McLauchlin, J., 1998. A small outbreak of listeriosis associated with smoked mussels. International Journal of Food Microbiology 43, 223-229.

Brillet, A., Pilet, M.-F., Prevost, H., Cardinal, M., Leroi, F., 2005. Effect of inoculation of Carnobacterium divergens V41, a biopreservative strain against Listeria monocytogenes risk, on the microbiological, chemical and sensory quality of cold-smoked salmon. International Journal of Food Microbiology 104, 309-324.

Bucio, A., Hartemink, R., Schrama, J.W., Verreth, J., Rombouts, F.M., 2006. Presence of lactobacilli in the intestinal content of freshwater fish from a river and from a farm with a recirculation system. Food Microbiology 23, 476-482.

Calo-Mata, P., Arlindo, S., Boehme, K., de Miguel, T., Pascoal, A., Barros-Velazquez, J., 2007. Current applications and future trends of lactic acid bacteria and their bacteriocins for the biopreservation of aquatic food products. Food Bioprocess Technology 1, 43-63.

Campos, C.A., Rodríguez, O., Calo-Mata, P., Prado, M., Barros-Velásquez, J., 2006. Preliminary characterization of bacteriocins from Lactococcus lactis, Enterococcus faecium and Enterococcus mundtii strains isolated from turbot (Psetta maxima). Food Research International 39, 356-364.

Casaus, P., Nilsen, T., Cintas, L.M., Nes, I.F., Hernández, P.E., Holo, H., 1997. Enterocin B, a new bacteriocin from Enterococcus faecium T136 which can act synergistically with enterocin A. Microbiology 143, 2287-2294

Cheigh, C.I., Choi, H.J., Park, H., Kim, S.B., Kook, M.C., Kim, T.S., Hwang, J.K., Pyun, Y.R., 2002. Influence of growth conditions on the production of a nisin-like bacteriocin by Lactococccus lactis subsp. lactis A164 isolated from kimchi. Journal of Biotechnology 95(3), 225-235.

Chen, H., Hoover, D.G., 2003. Bacteriocins and their food applications. Comprehensive Reviews in Food Science and Food Safety 2, 81-100.

Cleveland, J., Montville, T.J., Nes, I.F., Chikindas, M.L., 2001. Bacteriocins: safe, natural antimicrobials for food preservation. International Journal of Food Microbiology 71, $1-20$.

De Kwaadsteniet, M., Todorov, S.D., Knoetze, H., Dicks, L.M.T., 2005. Characterization of a 3944 Da bacteriocin, produced by Enterococcus mundtii ST15, with activity against Gram-positive and Gram-negative bacteria. International Journal of Food Microbiology 105, 433-444.

Deegan, L.H., Cotter, P.D., Hill, C., Ross, P., 2006. Bacteriocins: biological tools for biopreservation and shelf life extension. International Dairy Journal 16 (9), 1058-1071.

Dellaglio, F., Bottazzi, V., Troatelli, L.D. 1973. Deoxyribonucleic acid homology and base composition in some thermophylic lactobacilli. Journal of General Microbiology 74, 289-297.

Devlieghere, F., Vermeiren, L., Debevere, J., 2004. New preservation technologies: possibilities and limitations. International Dairy Journal 14, 273-285.

Drider, D., Fimland, G., Héchard, Y., McMullen, L.M., Prévost, H., 2006. The continuing story of Class Ila bacteriocins. Microbiology and Molecular Biology Reviews 70 (2), 564-582.

Duffes, F., Leroi, F., Boyaval, P., Dousset, X., 1999. Inhibition of Listeria monocytogenes by Carnobacterium spp. strains in a simulated cold smoked fish system stored at $4{ }^{\circ} \mathrm{C}$. International Journal of Food Microbiology, 47, 33-42.

Einarsson, H., Lauzon, H.L., 1995. Biopreservation of brined shrimp (Pandalus borealis) by bacteriocins from lactic acid bacteria. Applied and Environmental Microbiology 61, 669-674.

Ennahar, S., Asou, Y.,Zendo, T., Sonomoto, K., Ishizaki, A., 2001. Biochemical and genetic evidence for prodution of enterocins A and B by Enteroccus faecium WHE81. International Journal of Food Microbiology 70, 291-301.

Elotmani, F., Assobhei, O., 2004. In vitro inhibition of microbial flora of fish by nisin and lactoperoxidase system. Letters of Applied Microbiology 38, 60-65.

Fleming, H.P., Etchells, J.L., Costilow, R.N., 1975. Microbial inhibition by an isolate of Pediococcus from cucumber brines. Applied Microbiology 30, 1040-1042.

Frank, C.M.A.P., van Belkum, M.J., Holzapfel, W.H., Abriouel, H., Gálvez, A., 2007. Diversity of enterococcal bacteriocins and their grouping in a new classification scheme. FEMS Microbiology Reviews 31, 293-310.

Gálvez, A., Valdivia, E., Abríouel, H., 1998. Isolation and characterization of enterocin EJ97, a bacteriocin produced by Enterococcus faecalis EJ97. Archives of Microbiology $171,59-65$

Giraffa, G., 2003. Funcionality of enterococci in dairy products. International Journal of Food Microbiology 88 (2-3), 215-222. 
Gonzalez, C.F., Kunka, B.S., 1987. Plasmid associated bacteriocin production and sucrose fermentation in Pediococcus acidilactici. Applied and Environmental Microbiology 53, 2534-2538.

Handa, S., Kimura, B., Takahashi, H., Koda, T., Hisa, K., Fujii, T., 2005. Incidence of Listeria monocytogenes in raw seafood products in Japanese retail stores. Journal of Food Protection 65, 411-415.

Itoi, S., Abe, T., Washio, S., Ikuno, E., Kanomata, Sugita, H., 2008. Isolation of halotolerant Lactococcus lactis subps. lactis from intestinal tract of coastal fish. International Journal of Food Microbiology 121, 116-121.

Ivanova, I., Kabadjova, P., Pantev, A., Danova, S., Dousset, X., 2000. Detection, purification, and partial characterization of a novel bacteriocin substance produced by Lactococcus lactis subsp. lactis isolated from boza-Bulgarian traditional cereal beverage. Biocatalysis - Vestnik Moskovskogo Universiteta Kimia 41, 47-53.

Katla, T., Møretrø, T., Aasen, I.M., Holck, A., Axelsson, L., Naterstad, K., 2001. Inhibition of Listeria monocytogenes in cold smoked salmon by addition of sakacin P and/or live Lactobacillus sakei cultures. Food Microbiology 18, 431-439.

Ke, D., Picard, F.J., Martineau, F., Ménard, C., Roy, P.H., Ouellette, M., Bergeron, M.G., 1999. Development of a PCR assay for rapid detection of enterococci. Journal of Clinical Microbiology 37, 3497-3503.

Klaenhammer, T.R., 1993. Genetics of bacteriocins produced by lactic acid bacteria. FEMS Microbiology Reviews 12, 39-85.

Messi, P., Bondi, M., Sabia, C., Battini, R., Manicardi, G., 2001. Detection and preliminary characterization of a bacteriocin (plantaricin 35d) produced by a Lactobacillus plantarum strain. International Journal of Food Microbiology 64, 193-198.

Michel, C., Pelletier, C., Boussaha, M., Douet, D.-G., Lautraite, A., Tailliez, P., 2007. Diversity of lactic acid bacteria associated with fish and the fish farm environment, established by Amplified rRNA Gene Restriction Analysis. Applied and Environmental Microbiology 73 (9), 2947-2955.

Miller, K.W., Ray, P., Steinmetz, T., Hanekamp, T., Ray, B., 2005. Gene organization and sequences of pediocin AcH/PA-1 production operons in Pediococcus and Lactobacillus plasmids. Letters in Applied Microbiology 40 (1), 56-62.

Mora, D., Fortina, M.G., Parini, C., Manachini, P.L., 1997. Identification of Pediococcus acidilactici and Pediococcus pentosaceus based on 16S rRNA and ldhD gene-targeted multiplex PCR analysis. FEMS Microbiology Letters 151, 231-236.

Moreno, M.R., Leisner, J.J., Tee, L.K., Ley, C., Radu, C., Rusul, G., Vancanneyt, M., De Vuyst, L., 2002. Microbial analysis of Malaysian tempeh and characterization of two bacteriocins produced by isolated of Enterococcus faecium. Journal of Applied Microbiology 92, 147-157.

Nes, I.F., Holo, H., Fimland, G., Hauge, H.H., Nissen-Meyer, J., 2001. Unmodified peptidebacteriocins (Class II) produced by lactic acid bacteria. In: Dutton, C.J., Haxell, M.A., McArthur, H.A.I., Wax, R.G. (Eds.), Peptide Antibiotics - Discovery, Modes of Action and Applications. Marcel Dekker Inc., New York, pp. 81-115.

Nieto-Lozano, J.C., Reguera-Useros, J.I., Pelaez-Martinez, M.C., De la Torre, A.H., 2002. Bacteriocinogenic activity from starter culture used in Spanish meat industry. Meat Science 62, 237-243.

Nilsson, L., Ng, Y.Y., Christiansen, J.N., Jørgensen, B.L., Grótinun, D., Gram, L., 2004. The contribution of bacteriocin to inhibition of Listeria monocytogenes by Carnobacterium piscicola strains in cold-smoked salmon systems. Journal of Applied Microbiology 96, 133-143.

Osmanağaoğlu, Ö., Beyatli, Y., Gündüz, U., 2001. Isolation and characterization of pediocin producing Pediococcus pentosaceus Pep1 from vacuum-packed sausages. Turkish Journal of Biology 25, 133-143.
Pilet, M.-F., Dousset, X., Barré, R., Novel, G., Desmazeaud, M., Piard, J.-C., 1995. Evidence for two bacteriocins produced by Carnobacterium piscicola and Carnobacterium divergens isolated from fish and active against Listeria monocytogenes. Journal of Food Protection 58 (3), 256-262.

Pinto, A.L., Teixeira, P., Castilho, F., Felício, M.T., Pombal, F., Gibbs, P.A., 2006. Prevalence and serotyping of Listeria monocytogenes in Portuguese live bivalve molluscs sampled in various steps along the sanitary control process. Aquaculture Research 37 (11), 1112-1116.

Ringo, E., Gatesoupe, F.-J., 1998. Lactic acid bacteria in fish: a review. Aquaculture 160 317-322.

Sambrook, J.E., Eritsch, F., Maniatis, J., 1989. Molecular Cloning: A Laboratory Manual, 2nd ed. Cold Spring harbour Laboratory Press, Cold Spring Harbour, NY.

Schägger, H., Von Jagow, G., 1987. Tricine-sodium dodecyl sulphate-polyacrylamide ge electrophoresis for the separation of protein in the range from 1 to $100 \mathrm{kDa}$ Analytical Biochemistry 166, 368-379.

Strasser de Saad, A.M., Manca de Nadra, M.C., 1993. Characterization of bacteriocin produced by Pediococcus pentosaceus from wine. Journal of Applied Bacteriology 74 406-410.

Strompfová, V., Lauková, A., Simonová, M., Marciňáková, M., 2008. Occurrence of the structural enterocin A, P, B, L50B genes in enterococci of different origin. Veterinary Microbiology 132, 293-301.

Tahiri, I., Desbiens, M., Benech, R., Kheadr, E, Lacroix, C., Thibault, S., Ouellet, D. Fliss, I. 2004. Purification, characterization and amino acid sequencing of divercin M35: a novel class IIa bacteriocin produced by Carnobacterium divergens M35. International Journal of Food Microbiology 97, 123-136.

Todorov, S., Dicks, L.M.T., 2004. Effect of medium components on bacteriocin production by Lactobacillus pentosus ST151BR, a strain isolated from beer produced by the fermentation of maize, barley and soy flour. World Journal of Microbiology and Biotechnology 20, 643-650.

Todorov, S., Dicks, L.M.T., 2005. Pediocin ST18, an anti-listerial bacteriocin produced by Pediococcus pentosaceus ST18 isolated from boza, a traditional cereal beverage from Bulgaria. Process Biochemistry 40, 365-370.

Tomé, E., Teixeira, P., Gibbs, P.A., 2006. Anti-listerial inhibitory lactic acid bacteria isolated from commercial cold smoked salmon. Food Microbiology 23, 399-405.

Tomé, E., Pereira, V.L., Lopes, C.I., Gibbs, P.A., Teixeira, P.C., 2008. In vitro tests of suitability of bacteriocin-producing lactic acid bacteria, as potential biopreservation cultures in vacuum-packaged cold-smoked salmon. Food Control 19 (5), 535-543.

Van Reenen, C., Dicks, L.M.T., Chikindas, M.L., 1998. Isolation, purification and partia characterization of plantaricin 423, a bacteriocin produced by Lactobacillus plantarum. Journal of Applied Microbiology 84, 1131-1137.

Wu, C.-W., Yin, L.-J., Jiang, S.-T., 2004. Purification and characterization of bacteriocin from Pediococcus pentosaceus ACCEL. Journal of Agricultural and Food Chemistry 52 $1146-1151$.

Yamazaki, K., Suzuki, M., Kawai, Y., Inoue, N., Montville, T.J., 2003. Inhibition of Listeria monocytogenes in cold-smoked salmon by Carnobacterium piscicola CS526 isolated from frozen surimi. Journal of Food Protection 66 (8), 1420-1425.

Yang, R., Johnson, M., Ray, B., 1992. Novel method to extract large amounts of bacteriocins from lactic acid bacteria. Applied and Environmental Microbiology 58, 3355-3359.

Zuckerman, H., Bem Avraham, R., 2002. Control of growth of Listeria monocytogenes in fresh salmon using Microgard ${ }^{\mathrm{TM}}$ and nisin. Lebensmittel-Wissenschaft und Technologie 35, 543-548. 